UDC 621.372 .54

\author{
A. Zazerin, A. Orlov, Ph.D., O. Bogdan \\ National Technical University of Ukraine "Kyiv Polytechnic Institute», \\ 16 Polytechnichna Str., Kyiv, 03056, Ukraine.
}

\title{
Bragg reflector acoustic impedance RLC model
}

The simplified RLC model of Bragg reflector impedance was developed and presented in this work. The model allows the straightforward integration of the reflector's electrical behavior into the most of modern CAD systems as a part of complex devices and enables the precise evaluation of the output characteristics in a relatively wide nearresonant frequency range. This is especially important in the modelling of RF systems composed of thin film bulk acoustic resonators. The model verification was given including the analysis of the total impedance frequency dependence in wide and narrow frequency ranges, the model agreement examination for different number of layers and using various materials. The evaluation of agreement error for different frequency bands presented which allowed one to determine the limits of applicability of RLC model. An important advantage of proposed solution is the decreasing of calculation time and improving of optimization efficiency of complex $R F$ circuits with a large number of resonators. References 10 , figures 6 , tables 2 .

Keywords: Bragg reflector; BAW; resonator; RLC model.

\section{Introduction}

In recent years the progress in the field of bulk acoustic wave (BAW) piezoelectric resonators has led to the possibility of manufacturing of frequency selective systems with features which enable the efficient exploitation in the frequency range up to $10 \mathrm{GHz}$. High quality factor and electromechanical coupling coefficient of these BAW resonators led to the great performance especially in terms of cutoff rate and out-of-band rejection ratio. Filters based on BAW resonators stand good for their low transmission loss (lower than $0,5 \mathrm{~dB}$ in comparison with SAW filters), moderate energy consumption (tens of microwatts) [1] and can be integrated with active elements on a single chip which makes them very promising option applied to mobile communication devices.

At the same time the calculation of the frequency-loss characteristics of the filter based on BAW resonators represents a complicated engi- neering challenge. The developed for today and commonly used solutions in the field of BAW resonators simulation include a variety of onedimensional (BVD, Mason and its modifications Redwood and KLM) and three-dimensional physical models. The simplest Butterworth-Van-Dyke (BVD) model of resonator provides the electrical characteristics of the device in a narrow nearresonant frequency range, however it does not account for a variety of intrinsic real device effects. For instance the finite thickness of the electrodes leads to an eigenfrequency shift; the nonideal acoustic isolation and corresponding acoustic energy leakage reduce the effective bandwidth and quality factor.

On the other hand three-dimensional models which engage the finite element (FEM) calculation method allow estimating the characteristics of resonator with high precision taking into account even the edge reflection effects and arbitrary electrode geometry. A significant disadvantage of three-dimensional models is their calculation time and complexity of integration into modern RF circuit design software. Thus, in [2] the calculation of three-dimensional resonator with a circular steplike top electrode took more than 4 hours in COMSOL Multiphysics. In addition to above the output data suitable for application in CAD are typically standardized Touchstone files containing the frequency response of the device for a specific structural modification of the device. The features mentioned above seriously complicate the analysis of complex filters consisting of a large number of resonators and in fact eliminate the possibility of design parameters optimization.

The Mason model composition concept is a compromise solution which provides the accounting of main effects of real devices. Due to its consistency and sequential structure the model is often used to simulate the multilayered structures such as trending solidly mounted resonators (SMR) with Bragg reflector as acoustic energy isolation method. However, as a distributed parameters model based on electrical transmission lines it requires the appropriate software simulation frame-

(c) Zazerin A., Orlov A., Bogdan O., 2015 
work which was realized not in all CAD systems. After that the modelling of complex electronic circuits based on multilayered structures may be inefficient in many cases because of inexpediency of accounting for multipath acoustic wave propagation and rereflection in Bragg mirror structure.

The proposed method for simulation of periodic layered structures (particularly Bragg reflector) based on the development lumped element RLC model. Due to the simplified reflector stack model this approach will significantly increase the efficiency of calculation and optimization of complex filters based on SMR resonators with Bragg reflector acoustic isolation.

\section{Theoretical background}

To ensure the proper operation of bulk acoustic wave resonator the propagation of longitudinal waves should be enclosed by the volume of piezoelectric material. In other words the acoustic energy must be concentrated locally without leakage into other device parts. The acoustic energy localization can be performed by introducing the discontinuities into the acoustic wave propagation path, so that the latter is reflected. The most effective discontinuity is the air-solid material interface which is implemented in film bulk acoustic resonators (FBAR) design. Another approach is to create a periodic Bragg reflector used in SMR-type devices.

Unlike the FBAR structure, SMR resonators have the advantage of less sensitivity to reciprocal layers tension. Moreover the production process of SMR requires less technological steps and photolithography patterns. For one thing, the access window for sacrificial layer opening excluded as well as its removal. Another important effect of reflective layers in SMR as shown in [3] is a partial increasing of transverse stiffness of the piezoelectric layer which minimizes displacement caused by transverse waves and as consequence reduces the effect of parasitic resonances commonly observed in non-loaded layers of FBAR.

The arbitrary SMR structure is shown in Figure 1. Actually the resonator is represented by piezoelectric layer material sandwiched between two electrodes. Acoustic isolation is implemented as the interface air-solid above the top electrode and Bragg reflector stack under the bottom electrode which also acts supporting structure and heat sink.

Bragg reflector stack usually begins with low impedance $\mathrm{SiO}_{2}$ layer to obtain higher electromechanical coupling coefficient $\mathrm{k}^{2}$. This one also depends on the number of layers in reflector and the layers acoustic impedance ratio $Z_{L}$. Thus, $k^{2}$ improves with the increasing of impedance ratio due to less energy concentration outside the resonator. Furthermore the layers material significantly affects the quality factor of resonator [4].

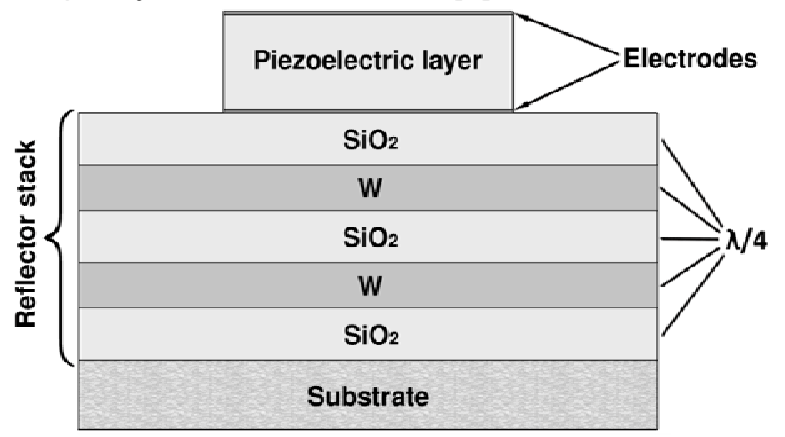

Fig. 1. The structure of SMR with Bragg reflector layers

A bunch of structure optimization algorithms developed and are used during the design of high effective acoustic reflector. The simplest and commonly used approach to model the longitudinal wave Bragg reflector is the selection of thickness of each layer which corresponds the quarter acoustic wavelength:

$$
f_{0}=\frac{V_{0}}{4 D_{0}}=\frac{V_{1}}{4 D_{1}},
$$

where $V_{0}, V_{1}$ - velocities of longitudinal acoustic wave in materials 1 and $2, D_{0}, D_{1}$ - layer thicknesses, $f_{0}-$ specified central frequency of the Bragg reflector.

Such an approach provides the maximum reflectance and acoustic isolation at the central frequency of reflector. The calculation of reflector's reflection efficiency and operational bandwidth based on electrical transmission lines analogy [5]. In this case the electrical parameters (impedance, velocity etc.) in the wave propagation equations are simply replaced by their equivalent acoustic ones.

In such a manner the analytical expression for the Bragg reflector acoustic impedance can be found by applying the recurrent relation for $i^{\text {th }}$ layer that represents a single T-section of the transmission line:

$$
Z^{(i)}=Z_{i} \frac{Z^{(i-1)}+Z_{i} \tanh \left(j \varphi_{i}\right)}{Z_{i}+Z^{(i-1)} \tanh \left(j \varphi_{i}\right)}
$$

where $Z_{i}$ - characteristic impedance of the $i^{\text {th }}$ layer, $\varphi_{i}$ - wave phase in this layer.

The output frequency response of the Bragg reflector using this approach can be represented as combination of the real and imaginary parts of the acoustic impedance. Herewith the total impedance has resonant frequency behavior with the minimum point of acoustic impedance at the center fre- 
quency $f_{0}$, which corresponds to maximum reflection.

\section{Model development}

The proposed model is based on the assumption of the small change in the derivative of the imaginary part of the reflector's acoustic impedance near the resonant frequency. In particular this part is responsible for the resonance frequency shift in the SMR. The calculated near-resonant dependencies of $\mathrm{im}(Z)$ for Bragg reflector configuration which consists of different number of $\mathrm{SiO}_{2}-\mathrm{W}$ layers depicted in Figure 2. Herewith, Z1 corresponds the case of one $\mathrm{SiO}_{2}$ layer on silicon substrate which is not reflector in fact and shown here for tendency illustration purposes. When considering the frequency dependence of imaginary part for different number of layers it becomes clear that the frequency behavior of obtained functions are very similar for $n>3$ and have almost linear nature. Thus, the normalized root mean square error value reached 0,989 when comparing $Z 3$ and $Z 9$ which indicates a small discrepancy between the curves for different number of layers.

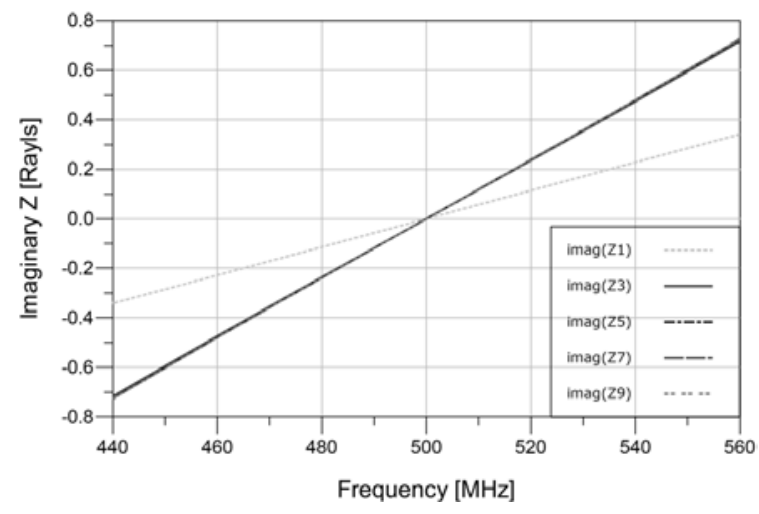

Fig. 2. The frequency dependencies of the imaginary component of the Bragg reflector acoustic impedance for 1, 3, 5, 7 and 9 layers of $\mathrm{SiO}_{2}-\mathrm{W}$

Submitted circumstances allow one to approximate the acoustic impedance of the Bragg re-

$$
Z 3_{B R}=\frac{Z_{1}^{2}\left(Z_{0}+Z_{1} s_{0} s_{1}\right)\left(Z_{s}+Z_{1} s_{1}\right)+Z_{0} Z_{1}\left(Z_{0} s_{0}+Z_{1} s_{1}\right)\left(Z_{1}+Z_{s} s_{1}\right)}{Z_{1}\left(Z_{0} s_{1}+Z_{1} s_{0}\right)\left(Z_{s}+Z_{1} s_{1}\right)+Z_{0}\left(Z_{1}+Z_{0} s_{0} s_{1}\right)\left(Z_{1}+Z_{s} s_{1}\right)},
$$

with the following replacements: $Z_{0}, Z_{1}, Z_{s}-$ characteristic impedances of $\mathrm{W}, \mathrm{SiO}_{2}$ and $\mathrm{Si}$ layers respectively, $s_{i}=j \cdot \tan \left(\varphi_{i}\right) \quad$ with phases $\varphi_{i}=2 \pi f \cdot D_{i} / V_{i}$, where $D_{i}, V_{i}$ - thickness and acoustic wave velocity in each layer. flector schematically in the form of RLC circuit which has a linear dependence of the imaginary component of the impedance near the resonant frequency $f_{0}$ that can be defined easily by interrelated parameters $\mathrm{L}$ and $\mathrm{C}$ :

$$
f_{0}=2 \pi \sqrt{L C} .
$$

The total impedance of such an equivalent circuit can be expressed as the following relation:

$$
Z_{R L C}=R+j 2 \pi f L+\frac{1}{j 2 \pi f C} .
$$

The proposed approach lays in fitting the impedance of RLC circuit for acoustic impedance of Bragg reflector and hence implies the equality of their derivatives at the resonance frequency $f_{0}$. As shown earlier the variation of the imaginary component of the reflector's total impedance is negligibly small with the number of layer of more than three. Therefore to simplify the calculation let us assume:

$$
\operatorname{im}\left[Z_{R L C}^{\prime}\left(f_{0}\right)\right]=\operatorname{im}\left[Z 3_{B R}^{\prime}\left(f_{0}\right)\right] .
$$

After substitution (4), one can obtain the following expression:

$$
\operatorname{im}\left[j 2 \pi L-\frac{1}{j 2 \pi C f_{0}^{2}}\right]=i m\left[Z 3_{B R}^{\prime}\left(f_{0}\right)\right] .
$$

The derivative of the RLC circuit impedance contains only the imaginary component that allows the simplification of this expression and after substitution capacity $\mathrm{C}$ from (3) one can achieve relations for parameters $L$ and $C$ :

$$
L=\frac{i m\left[Z 3_{B R}^{\prime}\left(f_{0}\right)\right]}{4 \pi}, C=\frac{1}{\pi f_{0}^{2}} \frac{1}{\operatorname{im}\left[Z 3_{B R}^{\prime}\left(f_{0}\right)\right]} .
$$

The formula for acoustic impedance of the three-layer Bragg reflector on specified substrate can be found by applying the recurrent relation (2):
The direct analysis of obtained expression for its submission to an equivalent circuit is non-trivial task. Conversely, the advantage of the proposed approach is to simplify the analysis using the following algorithm.

The derivative of the acoustic impedance in general form is represented by the next formula: 


$$
Z 3_{B R}^{\prime}=\frac{A_{i} s_{0}^{4} s_{1}^{8}+A_{i+1} s_{0}^{4} s_{1}^{7}+\ldots+A_{N-1} s_{0} s_{1}+A_{N}}{B_{i} s_{0}^{4} s_{1}^{8}+B_{i+1} s_{0}^{4} s_{1}^{7}+\ldots+B_{N-1} s_{0} s_{1}+B_{N}}
$$

where $A_{i}$ and $B_{i}$ - some coefficients of the tangents.

Since in this case Bragg reflector comprises quarter-wave layers the value of phase $\varphi_{i}$ for each tangent converges to $\pi / 2$ and consequently the value of tangent converges to infinity. This fact allows one to calculate the limit of the derivative function at the point $f_{0}$ actually leaving only the coefficients of the maximum degree of tangents:

$$
\lim _{f \rightarrow f_{0}}\left(Z 3_{B R}^{\prime}\right)=\frac{A_{i}}{B_{i}}=2 \pi j \frac{Z_{1}\left(Z_{0}^{2} Z_{s}^{2}-Z_{1}^{4}\right)\left(D_{1} V_{0}\left(Z_{0}^{2}+Z_{1}^{2}\right)+D_{0} V_{1} Z_{0} Z_{1}\right)}{V_{0} V_{1} Z_{0}^{4} Z_{s}^{2}}
$$

Taking into account $f_{0}=\frac{V_{0}}{4 D_{0}}=\frac{V_{1}}{4 D_{1}}$ for the quarter-wave reflector one can obtain the derivative of the acoustic impedance of the reflector at the frequency $f_{0}$ which comprises only the imaginary component:

$Z 3_{B R}^{\prime}=\pi j \frac{Z_{1}\left(Z_{0}^{2} Z_{s}^{2}-Z_{1}^{4}\right)\left(Z_{0}^{2}+Z_{0} Z_{1}+Z_{1}^{2}\right)}{2 f_{0} Z_{0}^{4} Z_{s}^{2}}$.

The values of $L$ and $C$ parameters can be achieved after substituting of this expression into (6). It appeared to be that these values depend on the characteristic impedances of the comprising layers and the resonance frequency $f_{0}$ which implicitly takes into account the thickness of the layers.

$$
\begin{aligned}
& L=\frac{1}{8 f_{0}}\left(\frac{Z_{1}\left(Z_{0}^{2} Z_{s}^{2}-Z_{1}^{4}\right)\left(Z_{0}^{2}+Z_{0} Z_{1}+Z_{1}^{2}\right)}{Z_{0}^{4} Z_{s}^{2}}\right), \\
& C=\frac{2}{\pi^{2} f_{0}}\left(\frac{Z_{1}\left(Z_{0}^{2} Z_{s}^{2}-Z_{1}^{4}\right)\left(Z_{0}^{2}+Z_{0} Z_{1}+Z_{1}^{2}\right)}{Z_{0}^{4} Z_{s}^{2}}\right)^{-1} .
\end{aligned}
$$

At the same time the function of real component of reflector's acoustic impedance has very complicated frequency dependence which and describes the energy loss in the resonator. The calculated curves for different number of layers of the Bragg reflector are shown in Figure 3.

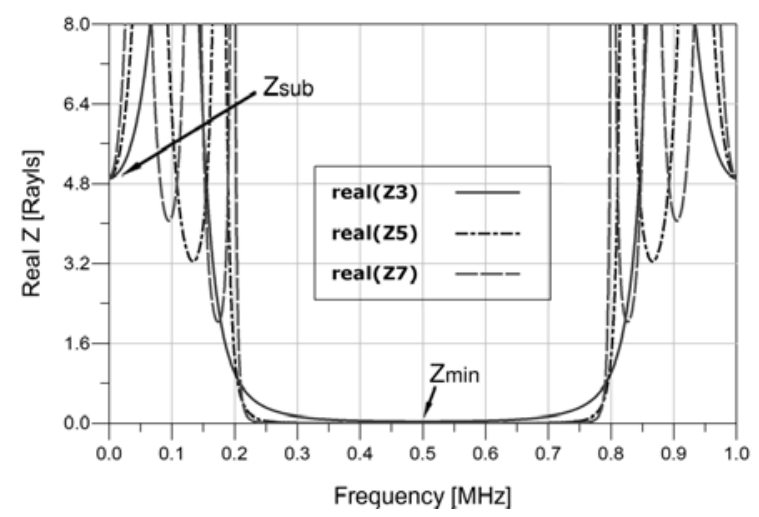

Fig. 3. The frequency dependencies of the real component of the Bragg reflector's acoustic impedance for 3, 5 and 7 layers of $\mathrm{SiO}_{2}-\mathrm{W}$
The keypoints of this function are the periodically repeated values at frequencies of 0 and 1000 $\mathrm{MHz}$ that corresponds to the acoustic impedance of the substrate $Z_{s}$, as well as a minimum point which can be found by substitution $f=f_{0}$ into the recursive relation for the acoustic impedance (2):

$$
\begin{gathered}
\lim _{f \rightarrow f_{0}} Z^{(1)}=Z_{1} \frac{Z_{s}+Z_{1} \tanh \left(j \varphi_{1}\right)}{Z_{1}+Z_{s} \tanh \left(j \varphi_{1}\right)}=\frac{Z_{1}^{2}}{Z_{s}}, \\
\lim _{f \rightarrow f_{0}} Z^{(n)}=\frac{Z_{1}^{n+1}}{Z_{0}^{n-1} Z s}=R_{f_{0}} .
\end{gathered}
$$

In a narrow near-resonance frequency band (470-500 MHz) the function of the real component is almost linear that allows one to approximate it as frequency independent resistance $R$. This element of the model is described by expression (14) and depends on the characteristic impedance of the layers as well as their quantity.

The periodic nature of the acoustic impedance function of the Bragg reflector can be modelled by additional RLC circuits connected in parallel as shown in Figure 4. This feature allows one to carry out the broadband frequency analysis of the device. The resonance frequency of each of the parallel circuits should be set by parameter $C^{(k)}=\frac{C}{(2 k-1)^{2}}$ with integer $k$ where $C$ corresponds to the relation (12).

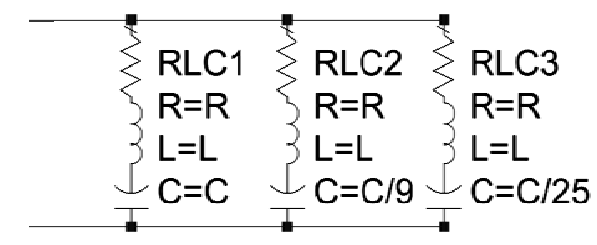

Fig. 4. Parallel RLC circuits simulates the periodicity of the acoustic impedance allowing the broadband frequency analysis 


\section{Model verification}

The verification of practical characteristics of RLC model of the Bragg reflector was carried out by a comparative analysis of the total impedance frequency dependence. In this case the standard Mason approach for the SMR-type structure (Fig. 1) was chosen as a reference model. The model's frequency behavior and simulation accuracy were under consideration along with its coherence under variation of frequently used layer materials and their quantity.

In particular, but not limited to this point, the frequency dependence in case of 5-layer reflector $\left(\mathrm{SiO}_{2}-\mathrm{W}-\mathrm{SiO}_{2}-\mathrm{W}-\mathrm{SiO}_{2}\right)$ on silicon substrate depicted in Figure 5. The thickness of the Si substrate for this and all subsequent calculations assumed equal to 7 microns. The thicknesses of the quarterwave layers were set in accordance with (1) to ob-

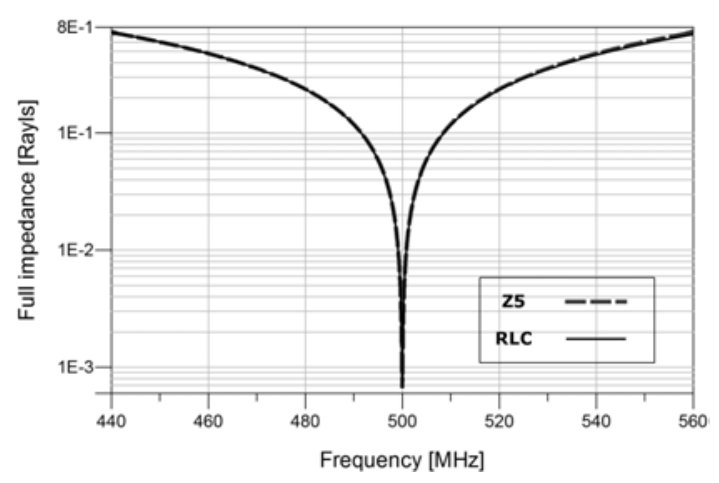

a) tain maximum reflectance at the central frequency of $500 \mathrm{MHz}$. The normalized root mean square error (NRMSE) was chosen as a model consistency criteria. It is often used to compare models outputs [6] and can be calculated using the following expression:

$$
N R M S E=1-\frac{\left\|Z_{\text {ref }}-Z_{\text {test }}\right\|}{\left\|Z_{\text {ref }}-\operatorname{mean}\left(Z_{\text {ref }}\right)\right\|},
$$

where || indicates the 2-norm of a vector (Euclidean norm), $Z_{\text {ref }}$ - the output data set of the reference model, $Z_{\text {test }}$ - the output data set of the test model. The NRMSE criteria value vary between $-\infty$ (bad fit) to 1 (perfect fit).

It is worthy of note that the following results were obtained using the MatLab numerical computing environment and Agilent Advanced Design System for electronic circuit simulations.

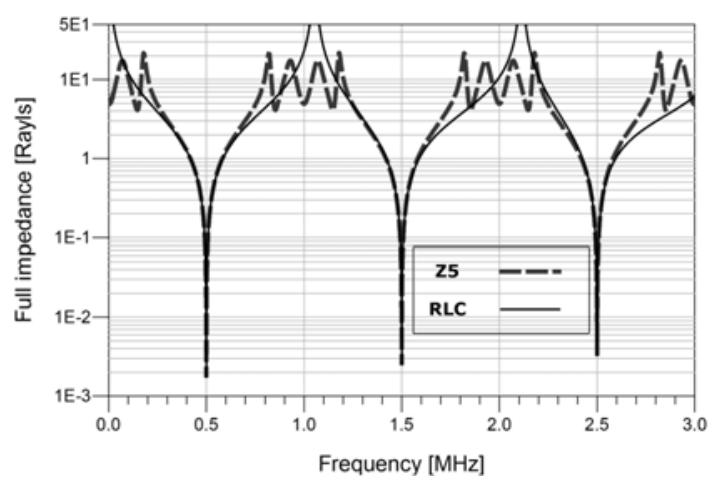

b)

Fig. 5. The total impedance frequency responses of the reference and RLC models in a narrow near-resonant (a) and wide (b) frequency ranges

As proceeding from the presented simulation results the RLC model has high agreement accuracy with the reference model in the frequency range of 440-560 MHz (Fig. 5, a). Thus, calculated NRMSE deviation reached the value of 0,968 in this case. In a wide frequency range the model consistency can be assessed only within periodically repeated resonances (Fig. 5, b). As noted before the quantity of higher harmonics is specified by additional parallel circuits of RLC model.

As shown in Figure 6, this fact is also confirmed by the calculation of NRMSE value for various frequency bandwidths with the central frequency $\mathrm{f}_{0}=500 \mathrm{MHz}$. As expected, the model consistency decreases with the expansion of the simulated frequency range. Notably for the range of $250 \mathrm{MHz}$ NRMSE coefficient reduced by $5 \%$ of the maximum value. Considering that the fractional bandwidth of nowadays BAW resonators reaches the value of $7-8 \%[7,8]$ (or $35-40 \mathrm{MHz}$ for $\mathrm{f}_{0}$ defined in this work) RLC model can be successfully applied in circuits to model the Bragg reflector with sufficient accuracy.

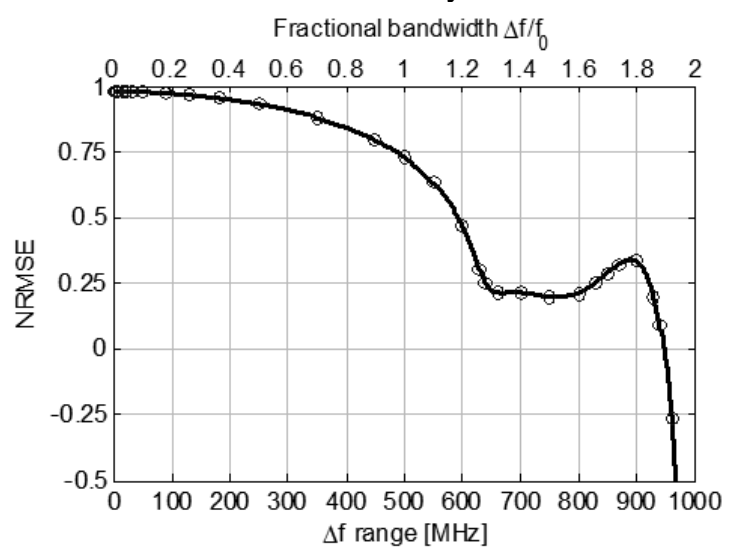

Fig. 6. The dependence of NRMSE value on absolute frequency bandwidth and fractional bandwidth $\Delta f / f_{0}$ 
The calculation results of the frequency response fit for varied Bragg reflector layers quantity are listed in Table 1. In this case the layer's materials of the model were $\mathrm{SiO}_{2}-\mathrm{W}$ for Bragg reflector and $\mathrm{Si}$ for substrate. The table contains data for narrow near-resonant $\Delta \mathrm{f}_{\text {local }}: 440-560 \mathrm{MHz}$ and wide frequency band $\Delta \mathrm{f}_{\text {wide }}: 0,1-1000 \mathrm{MHz}$.

Table 1. RLC model consistency for different number of Bragg reflector layers

\begin{tabular}{|c|c|c|}
\hline $\begin{array}{c}\text { Layers } \\
\text { quantity }\end{array}$ & $\begin{array}{c}\text { NRMSE } \\
@ \Delta \mathrm{f}_{\text {local }}\end{array}$ & $\begin{array}{c}\text { NRMSE } \\
@ \Delta \mathrm{f}_{\text {wide }}\end{array}$ \\
\hline \hline 1 & $-1,87$ & $-10,5$ \\
\hline 3 & 0,982 & $-1,22$ \\
\hline 5 & 0,968 & $-1,12$ \\
\hline 7 & 0,967 & $-1,07$ \\
\hline 9 & 0,967 & $-1,04$ \\
\hline 11 & 0,967 & $-1,02$ \\
\hline
\end{tabular}

According to the listed data the divergence rate varies slightly in a narrow frequency for different layers quantity while maintaining acceptable model accuracy. In a wide frequency range the NRMSE is predictably decreasing due to extending of Bragg reflector bandwidth and reduced influence of outof-band reflectance fluctuation.

Table 2 contains the calculations of model consistency for variable reflector layers materials. The value $Z_{L}$ represents acoustic impedance ratio of the thin film layer materials which affects the efficiency of acoustic energy isolation at the central frequency and the width of the reflection band. A commonly used approach is to utilize layer materials with a high impedance ratio $Z_{L}$, as it provides the greatest reflection bandwidth in longitudinal wave mode [9]. At the same time, the combinations of low impedance ratio, such as $\mathrm{ZnO}-\mathrm{SiO}_{2}$ are sometimes used to suppress spurious resonances due to high transverse waves reflection efficiency [10].

Table 2. RLC model consistency for different combinations of Bragg reflector layer materials

\begin{tabular}{|c|c|c|c|}
\hline \hline Materials & $\begin{array}{c}\mathrm{Z}_{\mathrm{L}^{-}} \\
\text {ratio }\end{array}$ & $\begin{array}{c}\text { NRMSE } \\
@ \Delta \mathrm{f}_{\text {local }}\end{array}$ & $\begin{array}{c}\text { NRMSE } \\
@ \Delta \mathrm{f}_{\text {wide }}\end{array}$ \\
\hline \hline $\mathrm{W}-\mathrm{SiO}_{2}$ & 7,9 & 0,97 & $-1,11$ \\
\hline $\mathrm{Mo}-\mathrm{SiO}_{2}$ & 5,0 & 0,93 & $-2,13$ \\
\hline $\mathrm{HfO}_{2}-\mathrm{SiO}_{2}$ & 4,1 & 0,9 & $-2,92$ \\
\hline $\mathrm{AIN}_{\mathrm{SiO}} \mathrm{SiO}_{2}$ & 3,0 & 0,8 & $-4,88$ \\
\hline $\mathrm{ZnO}-\mathrm{SiO}_{2}$ & 2,8 & 0,78 & $-5,17$ \\
\hline $\mathrm{Ta}_{2} \mathrm{O}_{5}-\mathrm{SiO}_{2}$ & 2,4 & 0,74 & $-5,91$ \\
\hline
\end{tabular}

Presented calculations showed high agreement accuracy in comparison to reference model in the range $\Delta \mathrm{f}_{\text {local }}$ for material combinations of high impedance ratio. Low-ratio material combinations with $Z_{L}$ of less than 3 exhibited NRMSE values of 0,74 0,78 which indicated the possibility of adequate evaluation of output characteristics only in relatively narrow frequency ranges.
The performed analysis of RLC model performance in terms of total acoustic impedance calculation showed the decreasing of calculation time of $52-56 \%$ in comparison to reference Mason model using Agilent ADS environment. The performance analysis of complex filters based on SMR resonators with presented Bragg reflector model became the subject of future research.

\section{Conclusions}

The paper presents a simplified lumped element RLC model of the Bragg reflector based on the assumption of small variation in the derivative of the acoustic impedance imaginary component function. The model verification including the frequency response analysis for different input parameters proved the model's applicability to evaluate the output characteristics of the Bragg reflector in longitudinal wave mode. Hence it opened the alternative possibility to calculate the dependence of reflection coefficient at the central frequency and reflector bandwidth on the number of layers. Also, the presented approach can be used to assess the applicability of various combinations of Bragg reflector and substrate materials.

Overall, the model provides high accuracy results in near-resonant frequency range of Bragg reflector (with fractional bandwidth up to $50 \%$ ). The possibility to connect the additional monotype RLC circuits provides the simulation of inherent periodic behavior of the real reflector. These advantages are especially important in modelling of the frequency response of thin film piezoelectric resonators, in particular higher resonant harmonics. Moreover the proposed RLC model allows one to account the resonance frequency shift determined by mass-loading and energy losses in device. As circuit solution it can be integrated into the most of modern CAD systems and used for accelerated calculation and assessment of the frequency characteristics of high-order filters based on SMR resonators, as well as for the optimization of their design parameters.

\section{References}

1. Nelson A. et al. (2011), A $22 \mu \mathrm{W}, 2.0 \mathrm{GHz}$ FBAR oscillator. IEEE Radio Frequency Integrated Circuits Symposium (RFIC). Baltimore, MD: IEEE, Pp. 1-4.

2. Yakimenko Y. et al. (2014), Film bulk acoustic resonator finite element model in active filter design/ Proceedings of the 37th International Spring Seminar on Electronics Technology (ISSE). Dresden: IEEE, Pp. 486-490. 
3. Newell W.E. (1965), Face-mounted piezoelectric resonators/ Proceedings of the IEEE. Vol. 53, No 6. Pp. 575-581.

4. Naik R.S. et al. (1998), Electromechanical coupling constant extraction of thin-film piezoelectric materials using a bulk acoustic wave resonator. IEEE Transactions on Ultrasonics, Ferroelectrics, and Frequency Control. Vol. 45, No 1. Pp. 257-263.

5. Lakin K.M., Wang J.S. (1981), Acoustic bulk wave composite resonators. Applied Physics Letters. Vol. 38, No 3. Pp. 125-127.

6. Granderson J., Price P. (2012), Evaluation of the Predictive Accuracy of Five Whole Building Baseline Models. Lawrence Berkley National Laboratory.

7. Baron T. et al. (2013), Wideband Lithium Niobate FBAR Filters. International Journal of Microwave Science and Technology. Pp. 6.
8. Izza N. et al. (2013), Film bulk acoustic wave resonator (FBAR) filter for Ku-band transceiver. Nanotechnology: Electronics, Devices, Fabrication, MEMS, Fluidics and Computational. Vol.2. Pp. 169-172.

9. Pensala T. (2011), Thin Film Bulk Acoustic Wave Devices. Performance Optimization and Modeling. Finland: Aalto University, Espoo. VTT Publications 756, P. 108.

10. Marksteiner S. et al. (2005), Optimization of acoustic mirrors for solidly mounted BAW resonators. Proceedings of IEEE Ultrasonics Symposium. Vol. 1. Pp. 329-332.

Поступила в редакцию 10 ноября 2014 2.

\title{
УДК 621.372 .54
}

\begin{abstract}
А.І. Зазерін, А.Т. Орлов, канд. техн. наук, А.В. Богдан
Національний технічний університет України "Київський політехнічний інститут", вул. Політехнічна, 16, корпус 12, Київ, 03056, Україна.
\end{abstract}

\section{RLC - модель акустичного імпедансу бреггівського відбивача}

В роботі представлена розроблена авторами RLC модель бреггівського відбивача. Завдяки спрощеності структури дана модель може бути легко інтегрована в більшість сучасних САПР $i$ дозволить з високою точністю визначати вихідні характеристики відбивача у відносно широкому близькорезонансному частотному діапазоні, що особливо важливо при моделюванні тонкоплівкових п'єзоелектричних резонаторів. Проведена верифікація моделі, що включила аналіз частотної залежності повного акустичного імпедансу у вузькому і широкому частотних діапазонах, дослідження узгодженості моделі при варіації кількості шарів бреггівського відбивача і при використанні різних матеріалів. Наведено розрахунок помилки узгодженості для різних частотних діапазонів, що дозволило визначити межі застосування моделі. Важливою перевагою запропонованої RLC моделі є збільшення ефективності розрахунку та оптимізації складних схем із застосуванням великої кількості резонаторів за рахунок скорочення часу розрахунку відбивача. Бібл. 10, рис. 6, табл. 2.

Ключові слова: бреггівського відбивач; BAW; резонатор; RLC модель.

\section{УДК 621.372 .54}

\section{А.И. Зазерин, А.Т. Орлов, канд. техн. наук, А.В. Богдан}

Национальный технический университет Украины «Киевский политехнический институт», ул. Политехническая, 16, корпус 12, г. Киев, 03056, Украина.

\section{RLC - модель акустического импеданса брэгговского отражателя}

B работе представлена разработанная авторами RLC модель брэгговского отражателя. Благодаря упрощенности структуры данная модель может быть легко интегрирована в большинство современных САПР и позволит с высокой точностью определять выходные характеристики отражателя в относительно широком околорезонансном частотном диапазоне, что

(c) Zazerin A., Orlov A., Bogdan O., 2015 
особенно важно при моделировании тонкопленочных пьезоэлектрических резонаторов. Проведена верификация модели, включающая анализ частотной зависимости полного акустического импеданса в узком и широком частотных диапазонах, исследование согласованности модели при вариации количества слоев брэгговского зеркала и при использовании различных материалов. Приведен расчет ошибки согласованности для различных частотных диапазонов, позволяющий определить границы применимости модели. Важным преимуществом предложенной $R L C$ модели является увеличение эфррективности расчета и оптимизации сложных схем с применением большого количества резонаторов за счет сокращения времени расчета отражателя. Библ . 10, рис. 6, табл. 2.

Ключевые слова: брэгговский отражатель; BAW; резонатор; RLC модель.

\section{Список использованных источников}

1. Nelson A. et al. A $22 \mu \mathrm{W}, 2.0 \mathrm{GHz}$ FBAR oscillator // IEEE Radio Frequency Integrated Circuits Symposium (RFIC). Baltimore, MD: IEEE, 2011. pp. 1-4.

2. Yakimenko Y. et al. Film bulk acoustic resonator finite element model in active filter design // Proceedings of the 37th International Spring Seminar on Electronics Technology (ISSE). Dresden: IEEE, 2014. pp. 486-490.

3. Newell W.E. Face-mounted piezoelectric resonators // Proceedings of the IEEE. 1965. Vol. 53, № 6. pp. 575-581.

4. Naik R.S. et al. Electromechanical coupling constant extraction of thin-film piezoelectric materials using a bulk acoustic wave resonator // IEEE Transactions on Ultrasonics, Ferroelectrics, and Frequency Control. 1998. Vol. 45, № 1. pp. 257-263.

5. Lakin K.M., Wang J.S. Acoustic bulk wave composite resonators // Applied Physics Letters. 1981. Vol. 38, № 3. pp. 125-127.

6. Granderson J., Price P. Evaluation of the Predictive Accuracy of Five Whole Building Baseline Models. Lawrence Berkley National Laboratory, 2012.

7. Baron T. et al. Wideband Lithium Niobate FBAR Filters // International Journal of Microwave Science and Technology. 2013. pp. 6.

8. Izza N. et al. Film bulk acoustic wave resonator (FBAR) filter for Ku-band transceiver // Nanotechnology 2013: Electronics, Devices, Fabrication, MEMS, Fluidics and Computational. 2013. Vol. 2. pp. 169-172.

9. Pensala T. Thin Film Bulk Acoustic Wave Devices. Performance Optimization and Modeling. Finland: Aalto University, Espoo 2011, VTT Publications 756, 2011. 108 p.

10. Marksteiner S. et al. Optimization of acoustic mirrors for solidly mounted BAW resonators // Proceedings of IEEE Ultrasonics Symposium. 2005. Vol. 1. pp. 329-332. 